\title{
Core Aspects of Dance: Schiller and Dewey on Grace
}

\author{
Joshua M. Hall
}

To cite this article: Joshua M. Hall (2017) Core Aspects of Dance: Schiller and Dewey on Grace, Dance Chronicle, 40:1, 74-98, DOI: 10.1080/01472526.2017.1274217

To link to this article: http://dx.doi.org/10.1080/01472526.2017.1274217

$$
\text { 曲 Published online: } 08 \text { Mar } 2017 .
$$

Submit your article to this journal

Џ Article views: 3

Q View related articles $\square$

View Crossmark data ¿ 


\title{
Core Aspects of Dance: Schiller and Dewey on Grace
}

\author{
Joshua M. Hall
}

\begin{abstract}
Part of a larger project of constructing a new, historically informed philosophy of dance, built on four phenomenological constructs that I call "Moves," this essay concerns the third Move, "grace." The etymology of the word "grace" reveals the entwined meanings of pleasing quality and authoritative power, which may be combined as "beautiful force." I examine the treatments of grace in German philosopher Friedrich Schiller, who understands it as playful, naïve transformation of matter; and in American philosopher John Dewey, for whom it represents rhythmic organism/environment reversal. I conclude by showing how "grace" can be used in analyzing various types of dance, which in turn suggests transformational potential for philosophy, dance, and society as a whole.
\end{abstract}

\section{KEYWORDS}

Grace; environment; John Dewey; Friedrich Schiller; Figuration

This essay is part of a larger project in which I create a historically informed philosophy of dance, called Figuration, built around four central concepts or "Moves." This new philosophy of dance has two major parts, analyzing (1) four basic concepts or "Moves"-namely "positure," "gesture," "grace," and "resilience"-within the context of (2) seven types or "families" of dance-namely "concert," "folk" (or vernacular), "societal," "agonistic," "animal," "astronomical," and "discursive." Devoted to the third of the four Moves, this essay examines the importance of grace for two major thinkers in the history of philosophy, Friedrich Schiller and John Dewey, and also touches upon the applicability of grace to the seven postulated families of dance. In the larger project, I define "grace" as "superabundantly playful, figure/ground reversing, meta-human gifting," but for reasons of space I limit the focus here to superabundantly playful and figure/ground reversing. ${ }^{1}$

The reason for my combined phenomenological and historical approach is that a phenomenological analysis of my own dance experience initially generated my theorization of the Moves (including grace), and the treatment of these concepts in diverse philosophical thinkers across the history of philosophy both buttresses the scope of their applicability and increases their subtlety and sophistication. By the word "phenomenological," I mean to signify a process in which I attend to the way I experience dance, or how it appears to my conscious, embodied being in the world. In this regard,

\footnotetext{
* I use the term "folk" to echo the effective use of this term in critical race theory and queer theory. For example, in The Souls of Black Folk (New York: Modern Library, 2003), W. E. B. Du Bois refers to "black folk" to convey a sense of disempowered peoples as fully human and deserving of the respect accorded to "ordinary" people. The reason for this effectiveness, perhaps, is that "folk" is a "down-to-earth" Germanic term.

๑) 2017 Taylor \& Francis Group, LLC
} 
I follow in the footsteps of the pioneering work of Edmund Husserl on phenomenology as further developed by Martin Heidegger. ${ }^{2}$ As for the title of the larger project, the word "figuration" derives from "figure," which comes from the Latin word schema, a transliteration of the Greek $\sigma \chi \eta \dot{\eta} \mu \alpha$. The Oxford English Dictionary (OED) offers twenty-six numbered definitions of "figure," the meanings of which include bodily shape, attitude, posture, mathematical form, conspicuous appearance, a diagram of the heavens, a move or set of moves in a dance, a musical phrase, and a metaphor. "Figuration" thus encapsulates in one word, via its etymological root, almost my entire project. My rationale for constructing a historically informed philosophy of dance is that I am convinced of the value of considering the contributions of major historical figures in philosophy vis-à-vis dance, because most panoramic efforts in the philosophy of dance thus far have been content to try to construct a comprehensive account of dance in the present-in other words, guided by one or several contemporary theoretical frameworks. One fringe benefit of my approach is that any trends that recur in the analyses of thinkers from across the history of Western philosophy would seem to be significant for any dance-studies theorist to consider today.

It is also worth noting that the discussion of families of dance amounts to an extensional definition of dance, or a list of types of things in the world to which the word "dance" refers. By contrast, an intensional definition of "dance" would attempt to describe the essential qualities that something would have to possess in order to count as dance. One might define "dance" as the art of movement for its own sake, as an example of the latter. Such a definition would be unacceptable, however, to many contemporary thinkers, because it would exclude many forms of dance, including ritual, that function efficaciously. In other words, it would mean that a dance that also served some instrumental purpose would be disqualified. The infamous inadequacy (or at least controversial status) of intensional definitions is the main reason why I prefer to emphasize the extensional approach. Although there is a certain degree of arbitrariness to the seven particular families I have selected, each reflects a "natural kind" of rhetoric of dance as applied to various phenomena, many of which are not conventionally understood as dance. Here, I follow "ordinary language" philosophers, such as J. L. Austin, in seeking ontological categories in the ways that everyday language users speak, rather than imposing metaphysical categories-despite the friction or dissonance between those metaphysical categories and everyday language. ${ }^{3}$

To elaborate on this point, by "dance" I mean the following seven clusters or "families" (to use twentieth-century philosopher Ludwig Wittgenstein's term) of meanings: concert dance, folk dance, societal dance, agonistic dance, animal dance, astronomical dance, and discursive dance. ${ }^{*}$ These families, then, are my own rough

\footnotetext{
* Wittgenstein is widely recognized as one of the most important philosophers of the twentieth century. In his early masterpiece Tractatus Logico-Philosophicus, he attempted to create the perfect artificial language, and in his later work, especially Philosophical Investigations, he explored the irreducibly contextual and behavioral aspects of human language. For more on Wittgenstein and other philosophers mentioned in this paper, consult online resources such as The Stanford Encyclopedia of Philosophy (https://plato.stanford.edu) and Internet Encyclopedia of Philosophy (http://www.iep.utm.edu/), keeping in mind the caveat that entries inevitably reflect the (often controversial) interpretations and personal philosophical commitments of contributing authors.
} 
attempt to get at the different kinds of phenomena that contemporary Western culture refers to as dances. Examples of each of the seven are ballet, clogging, salsa, tae kwon do, the pollen dance, "falling stars," and Pablo Neruda's poetry, respectively. At the end of this essay, I return to an analysis of each of these specific dance forms (as an exemplar of its family) with regard to how it is integrally linked with grace, as illuminated by Dewey and Schiller.

One potential objection to the larger project might be that these seven families seem too radically different to belong together at all. Consider, however, that there is at least one thing that all of them have in common-namely, that each is concerned with movement for its own sake. Moreover, one could argue that even in the case of ritual, dance is ultimately concerned with movement for its own sake. While rituals may be performed to achieve certain purposes or to fulfill certain societal functions, nonetheless the dance in a ritual reflects a somewhat arbitrary aesthetic or preferred/valued way of moving within a given community. And these ways of moving, across cumulative generations, ultimately amount to the way that the community as a whole moves through history. That is to say, external societies view a given society's ways of moving, especially in rituals, as arbitrary. As such, these ways of moving become interpreted, across the history of the society's interactions, as constituting part of its aesthetic essence (as it were). Consider, for example, the contrasting rituals of handshaking in Western countries versus bowing in China (among other countries).

In this essay, I focus on the third Move, grace (the other three Moves in my historically inflected philosophy being positure, gesture, and resilience). ${ }^{*}$ According to the OED, the word "grace" derives from the Ancient Greek kharis (meaning "to carry out, perform"), which suggests the two most important aspects of this Move for the purposes at hand. First, kharis is the source of the English words "charisma" and "charm," and means, at an etymological level, both "pleasing quality" and "authoritative power." Second, at a conceptual level, kharis is the root for the name of the ancient Greek goddesses of charm, beauty, nature, human creativity, and fertility, called the Karites (origin of the Latin caritas and English "charity") or "Graces." The significance here is that, historically, literature and the visual arts have depicted the Graces, minor goddesses, as dancers, which suggests that grace

\footnotetext{
* The Oxford English Dictionary (OED) defines the word "positure" as an archaic form of the word "posture." It is particularly useful in showing the links between the positing of poetry and the posing of dance because (1) "positing" is linked to poetry via the Greek word for poetry, poesis, which Aristotle uses to describe how various philosophers posit different phenomena (such as fire and love) as the basic material of the cosmos, and (2) "posture" is linked to "poses" that can be understood as the building blocks of a dance.

It might be helpful, at this point, to say a few words about the Moves in general. I find it meaningful that, although initially generated through a phenomenological analysis of my own dance experience-in an attempt to isolate a small cluster of concepts or constructs that could be considered central aspects of dance-they align nicely (without any premeditation on my part) with Rudolf Laban's Movement Analysis. See Jean Newlove, Laban for Actors and Dancers (New York: Routledge, 1993). More specifically, and to give a general sense of the meaning of the other Moves, they correspond closely to what Laban called the four effort dimensions: weight, space, flow, and time. Positure, like weight, involves the muscular tension of the body. Gesture, like space, involves different degrees of direction and indirection in moving through space to accomplish a given task. Grace, like flow, has to do with whether a motion is executed freely, as in a perfect conduit-relation to the environment, or with the expectation of sudden interruption. And resilience, like time, involves a distinction between sudden action and sustained movement.
} 
is a divine gift (as in "the grace of God" in the Judeo-Christian-Islamic theological tradition) and associated with dance. ${ }^{*}$

To explore grace, this essay examines the explicit treatments of dance in the works of the German poet, historian, and playwright Friedrich Schiller (1759-1805) and the American psychologist, political activist, and educator John Dewey (1859-1952). In the first section, I offer an analysis of grace as "beautiful force" with reference to three of Schiller's major works, namely On the Aesthetic Education of Man, "On Naive and Sentimental Poetry," and "Kallias or Concerning Beauty: Letters to Gottfried Körner."4 Specifically, I attempt to show how grace lies at the heart of (1) the play impulse, (2) the naive way of thinking/being/writing, and (3) the perfect transformation of matter that occurs in the case of beauty, respectively. In the second section, I analyze grace as “organism/environment reversal," drawing on Dewey's Art as Experience. ${ }^{5}$ Specifically, I attempt to show how grace, by its proximity to Dewey's concept of rhythm, illuminates the central importance of dance in his philosophy of art. To wit, dance is closely connected to both grace and rhythm, and Dewey refers to dance in Art as Experience more often than does any other author of a canonical text in the philosophy of art. Moreover, my analyses of these two thinkers constitute an opportunity to attend to two important philosophers whose work (especially in the case of Schiller) is largely ignored by philosophers today. My goal is to create a historically informed philosophy of dance with important implications for dance, philosophy, and their shared worlds.

\section{Grace as charm and power in Schiller}

Philosophy's studied indifference, throughout most of its history, to dance necessitates an indirect approach. Hence, I explore the ramifications and implications of grace in Schiller and Dewey first in general, larger contexts, then in contexts specific to dance.

The first two of the three texts that I analyze from Schiller, On the Aesthetic Education of Man and "Kallias or Concerning Beauty," are in the form of a series of letters, each constituting a kind of back and forth, or a dialogic process, between Schiller himself as the communicating figure, and the person to whom he is writing. ${ }^{\dagger}$ That is, Schiller's ideas, which occupy the foreground, make sense only as a result of the frame or background provided by his interlocutor. Some ideas are only (or best) expressed in dialogical form. Many philosophers think this is the reason that Plato, for example, wrote dialogues rather than treatises. And one can easily imagine many of Shakespeare's insights being less powerful, and in many cases impossible, had they not taken place in the back and forth of a conversation.

\footnotetext{
* Later in Greek history these goddesses were reduced in number to three: Algaea (which means "beauty" or "splendor"), Euphrosyne ("mirth" or "joy"), and Thalia ("good cheer" or "flourishing"), understood to be the daughters of Zeus and an Oceanid named Eurynome. For more on their connection to dance, see Francis Sparshott's groundbreaking essay, "On the Question: Why Do Philosophers Neglect the Aesthetics of the Dance?," Dance Research Journal, vol. 15 , no. 1 (1982): 5-30.

$\dagger$ On this dialogic process, see also Gediminas Karoblis, "Dance and Dizziness: Knut Hamsun's and Fyodor Dostoyevsky's Kinesthetic Imagination of Collapse," Dance Chronicle, vol. 38, no. 2 (2015): 161-87.
} 
Returning to Schiller-he wrote both series of letters in 1793, signed them with his own name, and initially sent them to real persons. Afterward, Schiller expanded and revised the letters for publication (in a journal he founded, called The Graces, among other venues). ${ }^{6}$ In the case of Aesthetic Education, the addressee is the Danish prince Friedrich Christian of the House of Schleswig-Holstein-Augustenborg. And in the case of "Concerning Beauty," the addressee is Gottfried Körner. The prince had provided support to Schiller, and Körner was a friend and prominent judge who was a great patron of the arts. Additionally, at least in the case of "Concerning Beauty," we know that Schiller's recipient also wrote a series of letters in response. ${ }^{7}$ But for both series of letters, Schiller had to tailor his thoughts in the letters to a specific person, embodied and socially positioned, in order to be maximally persuasive.

One can also find this back and forth at a second level in Aesthetic Education. The very first paragraph of the First Letter, where Schiller describes the letters (in the collected edition of them) as a series of "enquiries into Beauty and Art," proclaims that in such a task "one is compelled to appeal as often to feelings as to principles." ${ }^{8}$ Hence, the second type of back and forth happens at the level of content, or within the dialogical relationship between feelings and principles. Put another way, while any systematic inquiry requires principles, for Schiller the subject matters of art and beauty demand that feeling be given its due. A tension results from the process of intellectual inquiry, in which principles tend to become abstract and move away from feeling; hence, philosophers may, at times, seem to be apathetic or even dismissive toward feelings. Schiller, by contrast, desires to reintegrate the two.

Schiller directs the reader to the political world as early as the first paragraph of the Second Letter, which describes politics as "the most perfect of all works of art," and art as "the building up of true political freedom." Additionally, the Second Letter concludes by uniting aesthetic and political concerns, noting that, "it is through Beauty that we arrive at Freedom." 9 One finds already, in this formula, the two etymological halves of grace: the power (to be free) and the pleasing quality (of beauty).

Letters three and four introduce the specific aesthetic-political strategy that the rest of the letters will develop-a kind of coalition between the arts and politics. "Man," according to the Third Letter, "does not rest satisfied with what Nature has made of him, but possesses the capacity of retracing again, with his reason, the steps which she anticipated with him, of remodeling the work of need into a work of free choice." ${ }^{10}$ Note the circular or spiraling aspect of this project. The idea is not to make ourselves into objectively new beings, but to retrace our objectivity with our subjectivity, so that we may rationally affirm what already exists in us. Here again is the dialogical relationship: Schiller suggests we move from nature to culture and, from there, back to nature in a new way.

The Fourth Letter restates this project at the political level, defining the "pure, ideal man" as "represented by the State." The "unalterable unity" of this ideal man stems from his harmonized "existence" as an aesthetically educated human 
being. ${ }^{11}$ That is, such a man is the asymptotic ideal toward which aesthetic education aims. Here, Schiller brings the subjects of politics and aesthetics together again, through the rhetoric of music-specifically "harmony." (Schiller has been criticized as a forerunner of the aestheticizing of politics among the Nazis. ${ }^{12}$ )

A word with a similar musical denotation, but which adds connotations of concrete physicality, is found in the Sixth Letter, which speaks of "even tempering" as necessary for happy lives-foreshadowing a dance yet to come in the letters. The Seventh and Tenth Letters also foreshadow Schiller's discussion of dance, albeit for a very different reason-namely because dancing has long been strongly linked in the Western imaginary with "Negroes" and "savages." The Seventh Letter, in the Romantic tradition of idealizing the "noble savage," speaks of how "humanity may be respected in the negro [sic], while it is dishonoured in the thinker." A similar tone is struck in the Tenth Letter, where Schiller notes that "the pinions of genius" "border very closely upon savagery." 13 In short, Schiller's analysis integrates the feelings of music, the archetype of the passionate "savage," and the arts in general.

On a similarly violent note, the Eighth Letter includes the following passage, which prefigures similar claims later made famous in the work of Friedrich Nietzsche: "If Truth is to gain the victory in the struggle with Force, she must first become herself a force, and find some impulse to champion her in the realm of phenomena; for impulses are the only motive forces in the sensible world" (emphasis added). ${ }^{14}$ Force is clearly a physical phenomenon, and impulse is certainly a bodily one. Thus, Schiller advocates an aesthetic solution to the problem of truth's "victory," and dance would seem to be an ideal candidate for the job. Dance, I would argue, is particularly well-suited for transforming truth into a bodily force.

The Ninth Letter, hearkening back to Plato's arguments in his last dialogue, Laws, reveals additional insights related to violence and physicality. Here, Schiller argues for driving "away lawlessness, frivolity and coarseness from [people's] pleasure" in order to "imperceptibly banish [these qualities] from their actions and finally their dispositions." His admonition continues: "Wherever you find them, surround them with noble, great and ingenious forms, enclose them all round with symbols of excellence, until actuality is overpowered by appearance and Nature by Art." ${ }^{\prime 15}$ The opposites of lawlessness, frivolity, and coarseness are lawfulness, seriousness, and smoothness, which, by inference, Schiller ties to Art's overpowering of Nature. As a dancer, I think I am not alone in finding a strong resonance between Schiller's "noble, great and ingenious forms" and the disciplined movements of dance, which stand in opposition to the untrained, reckless, and restless ones of everyday life.

One might object that a tension exists between the claim for dance's seriousness and the previous attribution of playfulness, but I would argue that there exists such a thing as serious or earnest playfulness. If one considers the example of a child who is hard at work playing make-believe, spending hours meticulously crafting imaginary landscapes, the earnestness of play becomes immediately apparent. Moreover, dance's playfulness derives (at least in part) from dancers' willingness 
to be disciplined, working long hours, with exceptional focus and intensity, at something that may appear to be pointless and silly to many in our society.

Thus, using dance to flesh out Schiller's proposition, one could imagine a ring of dancers closing in on the ignorant novice in a great circle, as a symbol of the Art of political life transforming the human animal in its state of Nature. Moving from an imaginary exercise to actual historical precedent, consider the famous case of the court of Louis XIV, in which formal dance was intertwined with politics. ${ }^{16}$ More specifically, Louis invested heavily, and frequently took part in, dance performances; he even attempted to model the structure and appearance of his court on the musical harmony of the celestial bodies.

In short, various moments in Schiller's Aesthetic Education resonate in general with dance. However, explicit accounts of grace in particular also occur. The Tenth Letter marks the first of seven appearances of the words "grace" and "the Graces" in the following passage:

The man lacking in form despises all grace of diction as corruption, all elegance in social intercourse as hypocrisy, all delicacy and loftiness of demeanor as exaggeration and affectation. He cannot forgive the favourite of the Graces for brightening every circle by his company, for turning all heads towards his designs in public affairs, for impressing his spirit perhaps on his whole century by his writing, while he himself, the victim of drudgery, can with all his knowledge enforce no attention, move no single stone from its place. ${ }^{17}$ (emphasis added)

Here, several ideas emerge as worthy of note for the project of understanding grace. First, Schiller links grace and the Graces in successive sentences, invoking divinity in the arenas of both "microcosmic" and "macrocosmic" social worlds. That is, the gracefulness of people in the social world is intimately connected to the mythical grace of the Graces among the gods. (Schiller reinforces this connection in the next letter, when he asserts that "the path to divinity ... is open to [the human] in his senses" (emphasis in original). ${ }^{18}$ Second, Schiller links the grace of a person's diction to his political grace as a savvy citizen. In other words, speaking beautifully is the small-scale equivalent of climbing the political ladder. Third, Schiller again "cashes out" grace in terms of physical force in the actual world-in this instance, in a metaphorical way, with the image of a stone that cannot be moved without grace. Fourth, Schiller remains to this day what critical epistemologists call an "insider-outsider" in the world of philosophy-someone located on the fringes of a social group who can perceive that group from both insider and outsider perspectives. In light of Schiller's graceful writing and the implications of his ideas for aesthetics and the arts, his exclusion from the canon is ironic, but far from uncommon. Numerous figures occupy the margins of philosophy, who, despite their diversity, share with Schiller a rich writing style and a more inclusive and deferential treatment of dance. Examples include Étienne Bonnot de Condillac, Friedrich Nietzsche, Ralph Ellison, Julia Kristeva, and Luce Irigaray. ${ }^{19}$ 
To witness how grace functions in Schiller's thought one must turn to his Fourteenth Letter, which introduces the centrally important concept of "the play impulse"-an impulse combining the "sensuous" and "formal" impulses that he derives from Kant. The sensuous impulse, for both Schiller and Kant, is one that seeks variety, and does so through matter and its perceptual stimulations. The formal impulse, by contrast, seeks freedom, and does so through the laws of morality.

Schiller explains that the play impulse, insofar as it is a combination of the other two impulses, "will endeavor to receive [from the material world] as it would itself have produced, and to produce [with its moral freedom] as the sense [impulse] aspires to receive." Put differently, the play impulse wants the world to present itself as (1) the impulse's own beautiful perceptual creation, which also (2) can be further crafted in a morally satisfying fashion. Because of the play impulse, Schiller later explains, "everything actual," when "it comes into association with idea ... loses its seriousness, because it grows small" (emphasis in original). But also because of the play impulse, and simultaneous with this first effect, everything necessary (in terms of scientific materialist causation), "as it meets with perception ... puts aside its seriousness, because it grows light" (emphasis in original). ${ }^{20}$ Putting these two phenomena together, the play impulse sees the actual world as merely the indifferent raw materials with which to shape new aesthetic creations.

For Schiller, another helpful way of understanding the relationship among the three impulses, as well as the centrality of the play impulse, is to look at their respective objects. In the Fifteenth Letter, Schiller explains that the object of the sense impulse "may be called life in the widest sense of the word; a concept which expresses all material being and all that is immediately present in the senses" (emphasis in original). The object of the form impulse, on the other hand, "may be called shape, both in the figurative and in the literal sense; a concept which includes all formal qualities of things and all their relations to the intellectual faculties" (emphasis in original). The object of the play impulse, finally, "can therefore be called living shape, a concept which serves to denote all aesthetic qualities of phenomena and-in a word-what we call Beauty in the widest sense of the term" (emphasis in original). ${ }^{21}$ Beauty is thus, for Schiller, "living shape," and one could argue that no more fitting symbol for vital and dynamic shape exists than the dancer in motion.

Schiller reemphasizes the play impulse later in the Fifteenth Letter through his (perhaps surprising) claim that "in every condition of humanity it is precisely play, and play alone, that makes man complete." As if this were not a strong enough claim, he goes on to assert that "Man plays only when he is in the full sense of the word a man, and he is only wholly Man when he is playing" (emphasis in original). The implication here is that human beings and culture for Schiller are inherently and lightheartedly creative, constructive, and experimental. Schiller's claim that the essence of being human lies in the ability to play seems less overreaching, though, in light of his reference two sentences later to "the whole fabric of aesthetic art, and the still more difficult art of living." ${ }^{22}$ In other words, Schiller views human 
life as a kind of ongoing artwork, in which we both act as painter and serve as medium-canvas, acrylics, and vision. Extrapolating from Schiller, everyday life and the business of politics - as component parts of the "art of living"-may be seen as dances, or ways of moving gracefully through daily existence and its power negotiations.

Coming down from this pinnacle, however, Schiller concedes at the beginning of the Sixteenth Letter that "the utmost that experience can achieve will consist in an oscillation between the two principles" of sense and form. So the play impulse for Schiller is never fully realized at any given moment, but is rather a process of oscillating. In this way, one could argue that the play impulse resembles the process through which dancers respond to the sensuous rhythms of their music by creating forms (playfully). Even more specifically appropriate to dance, moreover, is Schiller's rhetoric (in the next paragraph) of "relaxing" and "tightening." The play impulse, Schiller claims, "must relax by tightening both [sensuous and moral] natures evenly, and it must tighten by relaxing both natures evenly." "23

Schiller closes this letter by reference to, on the one hand, the "melting beauty" necessary for the "tense man," and on the other hand, the "energizing beauty" vital for "the languid man." Both kinds of beauty, he elaborates, "dissolve" "in the unity of the ideally beautiful, just as those two opposite forms of humanity are absorbed in the unity of the ideal man." ${ }^{24}$ Again, Schiller seamlessly unites the personal and the political, by way of the ideal man, who is both aesthetically pleasing and politically persuasive. And again unification is achieved through the language of aesthetic physicality that is, arguably, powerfully suggestive of dance.

With a similar textual choreography, Schiller writes in the Seventeenth Letter of a deficit of "harmony" and "a lack of energy" as the two sources of human imperfection. He also writes there of the "taut" condition, either sensuous or intellectual, of a person in need of relaxing beauty. Schiller beautifully brings together all of these ideas in the first sentence of the Eighteenth Letter: "Through beauty the sensuous man is led to form and to thought; through beauty the spiritual man is brought back to matter and restored to the world of sense." ${ }^{25}$ Dance, again, seems particularly well-equipped to ground (in physical, tangible realities) those who float on spiritual planes and to inspire (through reflection) those too susceptible to their senses.

Near the end of the entire text, grace starts to take on a new dimension for Schiller. He refers to the "grace of Nature" as that which allows human beings the opportunity to achieve moral freedom, provided that beauty has tamed the restless (sense) impulse and brought the abstract (play) impulse back to everyday life. Schiller also describes "the faculty which is restored to [the human] in the aesthetic disposition" as "the highest of all gifts," and even as "the gift of humanity." ${ }^{26}$ In this way, Schiller's analyses, evocative of the etymology of grace-that is, beautiful force-connect explicitly with grace's conceptual meanings-that is, divine gifting.

The end of On the Aesthetic Education of Man also includes analyses that are particularly resonant with dance, thus fulfilling the foreshadowing I have identified 
in earlier letters. The first dance-resonant moment concerns a hierarchy of the fine arts based on the resistance, in a given art form's material, to taking on new forms: "The real artistic secret of the master consists in his annihilating the material by means of the form, and the more imposing, arrogant, and alluring the material is in itself ... the more triumphant is the art which forces back material and asserts its mastery over form" (emphasis in original). ${ }^{27}$ One can easily read dance into this central insight, because the dancer must discipline the body to such an extent that it appears to be but an outward expression of his/her inward form-making capability. Moreover, dance takes for its material source the human being as a wholebody, mind, and soul; moral freedom; and sensuous existence. Arguably no material is more resistant to new forms than the human body per se, which implies that the aesthetic transformation of the entire body-as in dance-is, on Schiller's terms, the most triumphant possible artistic accomplishment.

To support this claim, one need only appeal to the prevalence of dance rhetoric in Schiller's final few letters. First, Schiller writes in the Twenty-Sixth Letter of how "the intellect leaps out over the light to the objects." ${ }^{28}$ Leaping has always been an integral part of dance, at least as far back as Plato, and continuing to the present day. In fact, in many languages (such as Hebrew, Latin, and German) the same verb (in Latin, salir) means both "to leap" and "to dance."

Second, the Twenty-Seventh Letter refers to how animals "squander" their "superabundant life" "in joyous movements," and of "the leap to aesthetic play." 29 The history of philosophy abounds in comparisons (and even identifications) of expressions of joyous movement to dance. ${ }^{*}$ Moreover, we have seen the degree to which Schiller's play impulse resonates with dance.

Finally, in this same letter Schiller invokes dance by name for the first time in this collection, observing how this "lawless leap of play," mentioned earlier, "becomes a dance." This final letter also contains, alongside this specific reference to dance, three additional references to grace. ${ }^{30}$ I take these specific references to dance and grace, in close proximity with one another, to be the explicit manifestation of an underlying logic in this text. Put more strongly, they appear to constitute a climactic coming-to-awareness for Schiller of dance's importance for his thought.

To fully appreciate Schiller's concept of grace, it is pertinent to consider briefly two themes from his other major works-specifically the value of naiveté and beauty's transformation of matter. In "On Naïve and Sentimental Poetry," Schiller casually uses the word "grace" early in his discussion of the naive poet and poetry: "From the naive way of thinking there flows of necessity a naive expression, and it is the most important element of grace." ${ }^{31} \mathrm{He}$ defines "the naive manner of thinking" as that which "combines childlike with childish simpleness"; it is a manner of thinking that evokes "a feeling in which cheerful patronizing, respect and melancholy flow together" (emphasis in original). Schiller then defines naiveté per se as

\footnotetext{
* See, for a few examples, the thinkers noted above in a similar context, namely Condillac, Nietzsche, Ralph Ellison, Julia Kristeva, and Luce Irigaray.
} 
"a childlikeness, where it is no longer expected" (emphasis in original). In a footnote to this discussion, Schiller contrasts (a) the (positive) naïveté of "a free and healthy" child, who "dispenses with" "overly affected manners," with (b) the (negative) quality evinced by "the stiff posturing of the dance-master." 32 Thus, Schiller indirectly links grace and dance, and valorizes the playfulness of children, who typically perform the spontaneous, natural movements of dance, over the formal dance of professional adult dancers.

In "'Kallias or Concerning Beauty: Letters to Gottfried Körner," Schiller claims that "Beauty is nothing less than freedom in appearance." The reader will note that movement qua freedom is a typical way of describing dance as an art form. Moreover, in the subsequent (second) Kallias letter, Schiller makes another claim that gestures toward dance. He distinguishes between two different acts: "to give a concept of beauty and to be moved by beauty" (emphasis in original). Thus, Schiller not only emphasizes motion and beauty, but also distinguishes between them. And dance does the same, highlighting motion and beauty, which may (but need not) be combined as the beautiful unfolding of forms. The same Kallias letter also defines "form" as "an exhibition of freedom," and then delimits a "beautiful" form to that which "explains itself without a concept" (emphasis in original). ${ }^{33}$ Dance, too, articulates itself without need of intermediary (non-gestural) concepts.

In the same vein, several letters later (on February 23, 1773), Schiller uses the extended metaphor of a "workhorse" and a "palfrey" (a type of riding horse) to show the connection between, on the one hand, external constraints, and on the other hand, a natural freedom of movement. Schiller observes that the workhorse's "movement no longer springs from its nature," whereas the palfrey "has never become accustomed to exerting greater effort than it feels like exerting in its most perfect freedom," and therefore "moves ever so lightly, as if it weighed nothing at all." This description of defying gravity (a common trope for types of Western dance) already suggests a dance. This connection is then intensified by the next sentence, which Schiller sets off in quotes: "The specific form of the horse has overcome the nature of bodies, which must follow the rules of gravity, to such an extent that one is not reminded that it is a body at all" (emphasis in original). ${ }^{34}$ This is exactly what happens, for example, in skillful ballet. The dancer overcomes gravity and inertia to such an extent that the spectator begins to see lines, shapes, and movement, rather than persons.

Finally on this note, Schiller argues that, since a perpetually curving line is more beautiful than a jagged one-namely, because a "movement seems free" if "one cannot name the particular point at which it changes its direction"-one is "bothered by every dancing-instructor's intrusion into positions." 35 Although his words seem to criticize rather than affirm dance, the next paragraph reverses that impression. There, Schiller returns to the oscillation between the personal and the political already noted in connection with On the Aesthetic Education of Man. For this reason, that paragraph-reuniting dance and grace-serves well to conclude the foregoing analyses of Schiller. 
It is striking how one can develop gentility (beauty in social relations) from my concept of beauty. The first law of gentility is: have consideration for the freedom of others. The second: show your freedom. The correct fulfillment of both is an infinitely difficult problem, but gentility always requires it relentlessly, and it alone makes the cosmopolitan man. I know of no more fitting an image for the ideal of beautiful relations than the well danced and arabesquely composed English dance. The spectator in the gallery sees countless movements which cross each other colourfully and change their direction willfully but never collide. Everything has been arranged such that the first has already made room for the second before he arrives, everything comes together so skillfully and yet so artlessly that both seem merely to be following their own mind and still never get in the way of the other. ${ }^{36}$ (emphasis in original)

One has merely to recall the obligatory dance scenes in any film adaption of a Jane Austen novel, in order to picture what Schiller describes here. ${ }^{37}$ As the camera zooms into a close-up view of just one dancer or her partner, the viewer perceives the dance motions as free, voluntary, and expressive (in their subtle idiosyncrasies) of the singularity of each person. From a wide view of the entire dance floor, however, the dance motions appear to be necessary and automatic, and to follow the prearranged harmony of the celestial bodies. In short, the charm is in the details, while the power sustains the whole.

Synthesizing these analyses based on the etymology of grace in Schiller's On the Aesthetic Education of Man, "On Naïve and Sentimental Poetry," and The Kallias Letters yields the first element of the amplified conception of grace for the Figuration philosophy of dance: grace is superabundantly playful. The beauty and charm here lie in the "play" of the play impulse, the "naiveté" of the naive way of being, and the "beauty" that perfectly transforms matter. The power and force, by contrast, reside in the "impulse" of the play impulse, the "being" of the naive way of being, and the (according to Schiller) "perfect" transformation effected by beauty.

By these charming powers, in every sense of the phrase, dance engages in overcoming gravity and heaviness. This is particularly evident in children's play, social and romantic dances, and the seamless, acrobatic leaps of expert ballet dancers. But even apparent counterexamples, such as dances of mourning or war, though they might communicate gravitas, are not in fact unreflective. This is a crucial point. The conscious or ceremonial act of rendering a state of grief and/or the pursuit of detached skill lift the dancer out of the direct and unmediated experience of the event. That is, no matter how intense the grief of the dancer, s/he remains selfpossessed enough to execute premeditated or communally sanctioned steps.

\section{Grace as organism/environment role-reversal in Dewey}

While grace is important to Schiller, it holds equal, if not greater, significance for Dewey. Although one might summarize the meaning of "grace" for both Schiller and Dewey as "exemplary being in the world," for Schiller the emphasis would be on "exemplary," while for Dewey it would be on "being." In other words, grace is an axiological term for Schiller and a metaphysical one for Dewey. Above all, 
Dewey conceives of grace as the condition whereby an organism moves so smoothly and adaptively through its environment that, from the perspective of a human observer, the environment appears to move through the organism. ${ }^{*}$ The central features of this gracefulness are economy and continuity of movement, both of which are paradigmatic characteristics of dance. Appropriately, then, almost every time Dewey invokes grace in Art as Experience, he invokes dance as well. In fact, as noted above, Art as Experience boasts more references to dance than does any other classic text in the Western philosophy of art. The words "dance," "dancer," and "dancing" appear a total of twenty-five times in Art as Experience, and they only appear an average of five times in all of the others. ${ }^{\dagger}$ This means that Art as Experience mentions dance five times more often than the average canonical text in the history of Western aesthetics.

The first chapter of Art as Experience, "The Live Creature," opens with the claim that "the existence of works of art upon which the formation of an esthetic theory depends has become an obstruction to theory about them." In other words, receiving the artwork as product overemphasizes its thing-nature and facilitates an underestimation of the activity or process whereby that product was created. Against this backdrop, Dewey claims, "the actual work of art is what the product does in and with experience." Dewey sees his own contribution to the philosophy of art as that of restoring "continuity between the refined and intensified forms of experience that are works of art, and the everyday events, doings, and sufferings that are universally recognized to constitute experience." 38 This task implies that Dewey considers any sufficiently rarefied and/or intensified form of experience as a work of art.

One of Dewey's first and most memorable examples confirms this point. "The sources of art in human experience will be learned by him who sees how the tense grace of the ball-player infects the onlooking crowd." Note that Dewey locates the source of the artwork specifically in the dynamics of the how-that is, in the observer's learning of the relationship between the player's grace and the onlookers' aesthetic experience. As stated above, grace is one of the two central concepts in Dewey's book, the other being "rhythm," which appears for the first time shortly thereafter. There the context is a discussion of "feasting," "fighting,"

\footnotetext{
* For more on Dewey's view of grace, see Steven Fesmire, John Dewey and Moral Imagination: Pragmatism and Moral Ethics (Indianapolis: Indiana University Press, 2003), especially chapter 7, "The Moral Artist"; and Victor Kestenbaum, The Grace and the Severity of the Ideal (Chicago: University of Chicago Press, 2002), especially chapters 7 and 8, on the poet Wallace Stevens and divine grace respectively.

$\dagger$ This figure derives from Google searches for all appearances of the words "dance," "dancing," and "dancer." The "canonical" texts indicated are Theodor Adorno's Aesthetic Theory (4), Aristotle's Poetics (6), Clive Bell's Art (7), R. G. Collingwood's Principles of Art (18), Benedetto Croce's Guide to Aesthetics (0), Arthur Danto's Transfiguration of the Commonplace (6), Nelson Goodman's Languages of Art (20), G. W. F. Hegel's Introductory Lectures on Aesthetics (0), Martin Heidegger's "Origin of the Work of Art" (3), David Hume's "Of the Standard of Taste" (0), Immanuel Kant's Critique of Judgment (4), Friedrich Nietzsche's Birth of Tragedy (13), Plato's Republic (2), Plotinus's "On Intelligible Beauty" (Ennead V.8) (0), Arthur Schopenhauer's World as Will and Representation (6), Leo Tolstoy's What Is Art? (5), and Richard Wollheim's Art and lts Objects (0). If one brackets Dewey's fellow pragmatists/process philosophers (i.e., Nietzsche and Goodman), as well as Collingwood (given his idiosyncratic focus on community theater), the remaining texts refer to dance an average of only three times.
} 
"worship," and all the other "rhythmic crises that punctuate the stream of living." Dewey's central aesthetic concepts-grace and rhythm-resonate strongly with even the most casual dancer. Further, Dewey goes on to name dance explicitly in relation to basic human experience: "Dancing and pantomime, the sources of the art of the theater, flourished as part of the religious rites and celebrations." 39

In the second section of this first chapter, devoted to Dewey's uber-concept of "experience," grace and rhythm reappear (again in that order) in the first two pages. "The organs with which [the human] maintains himself in being are not of himself alone, but by the grace of struggles and achievements of a long line of animal ancestry." That is, Dewey sees human organs not as objects, but as manifestations of our evolutionary ancestors' adaptive actions. Rhetoric that can only come from the experience of dancing then shapes Dewey's two subsequent claims. First, life "consists of phases in which the organism falls out of step with the march of surrounding things and then recovers unison with it" (emphasis added). And second, the organism "grows when a temporary falling out is a transition to a more extensive balance of the energies of the organism with those of the conditions under which it lived" (emphasis added). It is "rhythm," finally, through which this "balance and harmony" are achieved. ${ }^{40}$

In the last three pages of the chapter, rhythm and grace each make a final appearance. Dewey writes that all "interactions that effect stability and order in the whirling flux of change are rhythms." In the following passage, Dewey again draws his exemplars of the aesthetic from animal behavior: animals exhibit "motion merging into sense and sense into motion-constituting that animal grace so hard for man to rival." ${ }^{41}$ It is a matter of effortless grace, in other words, for nonhuman animals to go seamlessly from action to perception and back again, and to do so without privileging one or the other.

To summarize the foregoing analyses of Dewey's first chapter, "grace" constitutes the "how" dimension of aesthetic experience and, thereby, its "evaluative" dimension. Rhythm, complementarily, comprises the "what" of aesthetic experience, and thereby its "ontological" dimension. Put differently, rhythm determines whether a given phenomenon in the course of experience counts as aesthetic. Further along, Dewey identifies rhythm with the following terms: "form," "rationality," "balance" and "symmetry." 42 Grace describes the success, goodness, or perfection of that which rhythm makes aesthetic. Put symbolically, if $x$ is insufficiently rhythmic, then $x \neq$ art. If $x$ is rhythmic but insufficiently graceful, then $x \neq$ high quality art. One could encapsulate Dewey's aesthetics with the statement: "That which is rhythmic is art, and that which is also graceful is good art."

Chapter 4 of Art as Experience, "The Act of Expression," contains two points germane to the present investigation. First, Dewey explicitly applies his concept of "transdermal transaction" to his aesthetics. He elaborates on this concept in the later book, Knowing and the Known (1949), authored with Arthur Bentley. "Organisms do not live without air and water, nor without food ingestion and radiation," the coauthors claim. "They live, that is, as much in processes across and 
'through' skins as in processes 'within' skins." ${ }^{43}$ In Art as Experience, Dewey writes, "The epidermis is only in the most superficial way an indication of where an organism ends and its environment begins." Why? A "living creature cannot secure what belongs to it without an adventure in a world." ${ }^{4}$ This claim constitutes Dewey's most significant contribution to the concept of grace. To wit, he re-envisions the organism and its environmental boundaries such that the body's physical limit (i.e., the skin) does not mark the organism's functional or metaphysical limits.

I would extend Dewey's proposition by arguing that the porous nature of the organism is the condition for the possibility of grace's figure/ground reversal. With the construct of figure/ground reversal, my intention is to capsize the Cartesian notion that subjects are active agents while objects in the world are merely passive recipients of activity. Instead, my paradigm recognizes the environment as active and agential. And going beyond a conception of figure/ ground reversal as mere perceptual or epistemological reversal, I propose a metaphysical understanding. To wit, in the phenomenon of grace, environments become the fundamental ontological figures, while organisms recede into the environments' ground.

The second point relevant to this study concerns Dewey's discussion of specific expressive arts. Among these arts, Dewey lists "dance and sport," defining them as "activities in which acts once performed spontaneously in separation are assembled and converted from raw, crude material into works of expressive art." 45 Note how Dewey situates dance close to everyday reality, which proximity calls to mind his overarching goal to restore the continuity between art and the aesthetics of everyday experience.

Dewey elaborates on this point in regard to dance only a few pages later, where he asserts that external communicability is necessary for a genuine act of aesthetic expression. "The war dance and the harvest dance of the savage," Dewey observes, "do not issue from within except there be an impending hostile raid or crops that are to be gathered." ${ }^{46}$ Dewey's point, as I take it, is not to purvey a modern/tribal or nature/culture distinction. On the contrary, he addresses what tribal art (e.g., the war dance) has in common with modern art (e.g., a dance performance): a communicative dimension in response to an external source, be it the opposing warring tribe or the audience. What is more, for Dewey, indigenous art is superior to modern Western art in that the former integrates function into itself, while the latter tends to be compartmentalized. Like Schiller, Dewey problematically invokes the "savage" as the connection between dance and contemporary Western aesthetics. That is, Dewey shares with Schiller a Romantic valorization of certain aspects of cultures placed lower on the Enlightenment's imperial/colonialist hierarchy. Or, more precisely, two simultaneous hierarchies are in play for Dewey, with non-Western society placed on the top rung of the first ladder (concerning the integration of the arts), and on the bottom rung of the second ladder (concerning artistic independence and complexity or sophistication). 
Similarly, a few pages later (and, again, as Schiller does) Dewey draws the connection between dance and childhood. Dewey writes of the "dancing" of "little children," and of the "rhythmic movement of happy childhood." 47 These remarks, taken together, constitute support for an argument I develop elsewhere that Western philosophy tends (1) to associate the inclination to dance with members of disempowered communities (including women, non-whites, non-heterosexuals, children, the "insane," etc.), and (2) to suggest a connection between tribal peoples (including tribal Africans and Native Americans) and Western children (do tribal peoples represent the stunted childhood of humanity?) by referring to the two groups in close proximity.*

Dewey also makes several other references to dance that merit brief mention. First, in chapter 3, "Having an Experience," he refers to "going through rhythmic movements in the dance." We have already seen how closely Dewey links grace and rhythm. This chapter also mentions "dances" in a list of aesthetic activities that Dewey views as emblematic of the balanced relationship between "doing" and "undergoing," which he claims makes aesthetic experiences so fulfilling.

Chapter 5, "The Expressive Object," names, as the first item in a list of necessary conditions for a successful expressive act, "the existence of motor dispositions previously formed" in "[a] surgeon, golfer, ball player, as well as a dancer." The same paragraph refers to "a graceful deer." 48 Thus, Dewey ties the "tense grace" of the baseball pitcher from chapter 1 directly to a dancer's grace.

In chapter 7, "The Natural History of Form," Dewey discusses how "the participation of man in nature's rhythms" eventually "induced him to impose rhythms on changes where they did not appear. The apportioned reed, the stretched string and taut skin rendered the measures of action conscious through song and dance." Dewey thus sees dance as vital to our creation of aesthetic rhythms, as distinct from human rhythms entirely shackled to nature. In this same paragraph, the philosopher attributes the power of visual artworks to bring "the very essence of the lives of [serpent, elk, boar] to realization" to the fact that such artworks depict those animals as "enacted in dance." Thus, dance helps us to understand the very natural phenomenon from which it helps us to achieve partial emancipation. Moreover, in this chapter Dewey asserts that dance appears "in all times and places." ${ }^{49}$ For Dewey, dance is a transhistorical, transcultural constant.

Finally, Dewey accords dance a pivotal place in his observations about the classification of the arts. Before beginning his own, provisional attempt at such a classification, Dewey claims that dance has been classified as "a mixed art" because it has

\footnotetext{
* For this claim's detailed support from feminist philosophers and critical race theorists, see Joshua M. Hall, "St. Vitus' Women of Color: Dancing with Hegel," Comparative and Continental Philosophy, vol. 9, no. 1 (2017), forthcoming; Joshua M. Hall, "Self-Mimetic Curved Silvering: Dancing with Irigaray," Journal of French and Francophone Philosophy, vol. 22, no. 1 (2014): 76-101; Joshua M. Hall, "Reattaching Shadows: Dancing with Schopenhauer," PhaenEx: Journal of Existential and Phenomenological Theory and Culture, vol. 9, no. 1 (2014); Joshua M. Hall, "Syncopated Communities: Dancing with Ellison," Southern Literary Journal, vol. 45, no. 2 (2013): 57-71; Joshua M. Hall, "Revalorized Black Embodiment: Dancing with Fanon," Journal of Black Studies, vol., 43, no. 3 (2012): 274-88; and Joshua M. Hall, "Choreographing the Borderline: Dancing with Kristeva," Philosophy Today, vol. 56, no. 1 (2012): 49-58.
} 
to do with both spatiality and temporality. This alone, he claims, constitutes "a reductio ad absurdum of the whole rigid classificatory business." power of dance for Dewey, that it can single-handedly reduce a philosophy of art to ruins. Presumably, theater and opera, which also incorporate spatial and temporal dimensions, possess the same power, but they do not seem to be uppermost in Dewey's mind as aesthetic continuities with everyday experience.

Dewey's novel, minimalist approach to this classification task involves only two types of art, which he terms the "automatic" and the "shaping." The automatic arts in Dewey's sense take the combined unit of the "mind-body" as their medium, while the shaping arts "depend to a much greater extent upon materials external to the body." Of the automatic arts, Dewey takes "dance" as his first example. For Dewey, dance includes "cultivation of voice, posture, and gesture," which "add grace to social intercourse." Counter-intuitively, the shaping arts-that is, the customary pantheon of painting, sculpture, architecture, music, and poetry-depend for their very aesthetic status on the automatic arts, including dance. And this is true for Dewey even though these automatic arts do not include a single traditional fine art. "Something of the rhythm of vital natural expression," Dewey elaborates, "must go into carving, painting, and making statues, planning buildings, and writing stories." Dewey then crystallizes his point: what must enter into the other arts is "something as it were of dancing" (emphasis added). ${ }^{51}$ In other words, Dewey insists that every art is necessarily, qua art, a kind of dance. Hence, each of the traditional five fine arts of poetry, music, painting, sculpture, and architecture depends in some manner on dance. Although one might counter that Dewey is talking about the process of art making rather than the artworks as final products, recall that Dewey explicitly defines the artwork as the process of the transformation of human experience. An artwork is not, therefore, the object or material ground of this transformation.

Synthesizing these conceptual analyses of grace in Dewey's Art as Experience yields the second aspect of the amplified conception of grace for the Figuration philosophy of dance: grace is figure/ground reversing. In other words, grace as a phenomenon is the result of a kind of gestalt switch. In this switch, more precisely, the object that is normally perceived as foreground becomes background. And the object that normally constitutes the background becomes the foreground.

To clarify, this switch is something akin to the moment, during the viewing of an Impressionist painting, when one stops seeing the brushstrokes as the inert application of color to the canvas, and experiences the carefully shaped mounds of oil paint as themselves central to the artwork-as if one were running one's fingers over the painting like a bas-relief map. An organism is graceful, in this sense, when it effaces its own particularity to such an extent that it becomes merely a confluence of both its inner flow and the outer currents that condition and transcend it. So, too, a graceful dancer becomes a mere occasion for the virtuosity of both the materials and the environment (including stage decor costuming, and dancers' bodies). 
Put differently, aesthetic gracefulness always takes place against a certain backdrop, a complex environment. And expression only becomes aesthetic through the organism's (or artist's, or artwork's) Deweyan "transactions" with this environment. These transactions, or complex interactions, highlight the raw materials that have been artistically reworked rather than merely deposited in an unassimilated state.

\section{The resultant move of grace in the philosophy of figuration}

Synthesizing my etymological analyses of grace in Schiller with my conceptual analyses of grace in Dewey, I would propose that the Move I call "grace" can be understood, in part, as a superabundantly playful phenomenon of figure/ground reversing. To rehearse the insights elaborated above, grace is superabundantly playful (from Schiller) insofar as it has to do with living shape, or beauty, which is the object of the play impulse. And grace is figure/ground reversing (from Dewey) insofar as it is the result of an organism-as-figure adapting so perfectly to its environment-as-ground that the environment seems to be moving through the organism instead of vice versa.

To connect Figuration theory to another theoretical discourse on dance, the Move of grace may be seen as closely related to Laban's analytical concept of "Flow," which involves the way that a body moves through personal and objective space. According to Laban for Actors and Dancers, a concise introduction to Laban's work written by his student Jean Newlove, Laban conceptualizes movement as inherently linguistic, specifically as "a two way language process through which the human body could communicate by giving and receiving messages." Newlove also claims that, for Laban, "Dance is to movement as poetry is to prose." ogy reinforces Figuration's claim that poetry constitutes a privileged access to dance.

The basis of Laban's work, Newlove explains, is the "kinesphere," the "space within our reach, our 'personal' space." Within this space, Newlove continues, "the four motion factors, Space, Time, Weight and Flow can influence the movement and attitude of an individual," and any given human "action requires ... all four." ${ }^{23}$ More specifically, a movement can range, on a set of multiple continua, from (1) "flexible" to "direct" in how it traverses space, (2) "sustained" to "sudden" in how it consumes time, (3) "light" to "strong" in its attitude toward weight, and (4) "free" to "bound" in how it flows. ${ }^{54}$ Combining the values of three of Laban's four variables (Space, Time, and Weight), generates what Laban calls the "Eight Basic Effort Actions," namely "press, wring, glide, float, thrust, slash, dab, flick." Against this backdrop, Laban's specific movement quality of Flow, which ranges from "bound" to "free," may be compared to Figuration's Move of grace, in this regard: both Flow and grace concern the aesthetics of communication or the style of the material basis of the communication. As Newlove puts it, "Flow can be related to precision and progression." 55 
To contemplate these insights from Laban in a way consonant with Figuration, the Move called "grace" constitutes the "how" dimension, the metamorphoses or transformations phenomena undergo as organisms and environments flow through each other in acts of communication. Figuration thus finds, in the concept of grace, the modality of its primary activity, namely the carrying out of communication. The critical dimension of this aspect of Figuration for philosophy is its claim that the aesthetic dimension of an activity always involves a transgressive self-overcoming of the limitations of the concept "human." (Here, I use the word "transgressive" in its positive sense, much as queer theorists do when they valorize the willful violation of repressive norms.) More specifically, these transformations involve transactions between (1) seriousness and gravity, (2) the human body's physical boundaries and the environment, and (3) the human being's metaphysical boundaries and the opposing poles of the animalistic and the divine.

How does the critical function of grace play out in actual analyses of members of the seven families of dance mentioned at the beginning of the essay? Below, using a particular example from each of the seven families, I explore the explanatory potential of Figuration philosophy. I begin with the conventional or commonsensical usage of the Move, and move on to the two adjectival aspects and the one substantive core of the amplified philosophical construct. Additionally, in the case of the literal/human dances, I briefly consider formal insights into the logic or structure of dance movement per se. For this, I draw on the technical studies of Rudolf Laban and André Levinson.

To summarize my argument thus far, the commonsense meaning of "grace" is "an aesthetically pleasing and seemingly effortless quality of movement." The first amplified aspect is superabundant playfulness; the second amplified aspect is figure/ground reversal; and the substantive core is meta-human gifting. By the latter phrase, I mean that the grace of dance is something that precedes humanity, both in the sense of animality and also of divinity; it transcends what it is to be human and resituates human existence in relation to the rest of the cosmos. As evinced in the tenth-to-eleventh-century philosopher Abu 'Ali al-Husayn ibn Sina (usually Latinized as "Avicenna"), of present-day Uzbekistan, dance is metahuman gifting insofar as it is the mark of the celestial beings-that is, the planets understood as angels-who in medieval Judeo-Arabic metaphysical systems provided revelation to the prophets, decipherable in the planets' astronomical orbits around the godhead. ${ }^{56}$

For ballet, the commonsensical account of grace leads to the ease, beauty, and apparent weightlessness with which dancers move through space. Examples range from the "how" of the fluttering steps executed en pointe to that of the bounding leaps of virtuosos such as Mikhail Baryshnikov. Grace finds ballet's superabundant playfulness in the frequency with which dancers imitate imaginary beings and symbolize light and airy nonhuman aspects of the world. The figure/ground reversal of ballet manifests in the way ballet almost completely hides the awkward and bulky humanity of the dancers in lines and flows. And the meta-human gifting of 
ballet lies in the fact that it transforms the human dancer into a kind of holy animal, like a pure dove, devoid of speech and possessed of a radiance such as might result from staring into the face of a god. To paraphrase these insights at the level of the family of concert dance in general, according to the Figuration philosophy of dance, the grace of concert dance consists in a playful ritual in which the outlines of a human world dapple the backdrop of self-effacing human beings, who are crisscrossed and transcended by a play of forces that both predate and spring beyond mundane human existence.

Beginning with Laban, the grace of ballet derives in part from its energetic extensions of the human body into regions of the kinesphere and dynamosphere that are usually neglected in everyday movement. Additionally, grace concerns ballet's privileging (over the body) of the invisible lines and shapes that the body metaphorically traces through space, especially in Laban's figure of the icosahedron. ${ }^{57}$ Levinson maintains that ballet's grace derives directly from its vertical orientation, the phenomenon of turnout exemplified in the five positions, and the rising of the body on pointe shoes. All three phenomena, for Levinson, remove the body from its gravitational human particularity, and toward a weightless, geometric ideality. ${ }^{58}$

For clogging, commonsensical grace manifests in the unwavering smiles, the uncompromisingly erect upper bodies, and the untiring whirls of legs and feet under piston-like knees. Grace finds superabundant playfulness in the strenuous legwork pounding into the ground toward no practical end. Figure/ground reversal reveals itself in the strong emphasis placed (visually) on the bending and rising of knees and (audibly) on the contact of feet with ground-two core aspects of human locomotion, without which the entire edifice of civilization would be impossible, but which must fade into the background in everyday life to permit focus on the sophisticated work of the hands, mouth, and frontal lobes. And metahuman gifting in clogging lies in the fact that the dancers' bodies are transformed into, and re-presented as, precision machines. They are comparable, in this way, to the machines on a Ford assembly line or in a steel mill and symbolize the ruckus of the human being channeled into unmediated production. To paraphrase these insights at the level of the family of folk dance in general, according to Figuration, the grace of folk dance consists in its making light, in every sense of that phrase, of the community's practical pursuits, by emphasizing the stylistic aspects of practical movement, and thereby emphasizing the nonhuman forces that sustain those pursuits.

From Laban's perspective, clogging's grace would perhaps lie in its imaging of long-standing rituals in Appalachia, such as the rigid movement patterns involved in life in the coal mines and steel mills-specifically the use of the two effort actions he terms "slashing" and "punching." In clogging's case, the knees slash through the air, and the legs punch the ground in what Laban terms "stamping." 59 As for Levinson, he would probably deny clogging any grace whatsoever, in part because it is a folk/vernacular dance form, which for him is necessarily mechanical and animalistic; and in larger part owing to its history as a fusion of Irish step 
dancing and African-American tap. In regard to Africana dance, Levinson observes that its greatest dancers, among whom he counts Josephine Baker, can only achieve individual grace either by leaving behind these "primitive" dances, or by transforming them into hybrid dance forms - that is, by fusing them with what he terms more "civilized," Western concert dances (such as ballet). ${ }^{60}$

For salsa, the notion of commonsensical grace lies in the smoothness with which bodies move individually, in partnership, and in communal manipulation of space. Grace finds superabundant playfulness in salsa's redeploying of erotic, romantic, and athletic skill sets in the context of a public space dedicated to intimate entertainment. Figure/ground reversal manifests in the fact that such skillful movements-which normally work best when they appear effortless and self-effacing (in actual courtship, seduction, and athletic competition) - in salsa constitute the phenomena in which the dancers channel their complex individuality. And metahuman gifting in salsa lies in the fact that the best dancing requires both (1) surrendering to one's animal instincts, and also (2) offering up one's own finite body to the godlike ideals of beauty and prowess. To paraphrase these insights at the level of the family of societal dance in general, according to Figuration, the grace of societal dance consists in practicing, in a casual public setting, vital intimate skills rooted in abilities much older than humanity and symbolizing perfection infinitely beyond it-but practicing them as though they were instead merely ornamental.

Laban's perspective on salsa's grace, which I infer from his analogy between fighting and dance, lies in the way that, during partnering, the two dancers' kinespheres interact in the mode of an attacker and defender. In this way, the grace of salsa foregrounds the antagonistic dimension of gendered romantic interaction. ${ }^{61}$ Given the Spanish/Moorish ancestry of salsa, Levinson's analyses of traditional Spanish dance are also relevant. In brief, Levinson argues that Spanish dance is a hybrid of two formal principles that he identifies in "Western" and "Eastern" dance, respectively. To wit, "the West" finds its emblem in outward extension; "the East," in inward enclosing; and the Spanish hybrid is thus the curve manifested by the letter "S," winding forever between its Arabic-African ancestry and its European parentage. ${ }^{62}$

For tae kwon do, the commonsensical idea of grace rests in the smooth and apparently effortless breaking of wood and the transition from one move to another in a "form" or choreographed series of attacks and defenses. Grace finds superabundant playfulness in the fact that these activities, though designed for combat and warfare, appear in tae kwon do in controlled settings, with either imaginary or staged opponents. Figure/ground reversal manifests in the fact that movements useful for defense against physical violence function to systematically pursue the expressly stated purpose of achieving psychological discipline and tranquility. And meta-human gifting in tae kwon do lies in the practitioner's attempt to take a godlike, comprehensive view of combat, thus allowing her/him to compensate for the evolutionary loss of "animalistic" means of self-defense such as fur or claws. To paraphrase these insights at the level of the family of agonistic dance 
in general, according to Figuration, the grace of agonistic dance consists in makebelieve reenactments of combat, facilitated by emphasizing the non-combative benefits of such reenactments - a project that can be understood as a divinely ambitious recreating of humans in the image of the animal playing of our evolutionary forbears.

For the pollen dance of the honey bee, the commonsensical notion of grace pertains to the ability of such brief and localized activities to enable the nutritional continuity of the hive. Grace finds superabundant playfulness in the pollen dance's dramatic recreation, inside the hive, of the actual foraging for nectar outside the hive. Figure/ground reversal manifests in the fact that the pollen dance works by subordinating the individuality of the dancing bee to its communicative function of "dancing" a literal roadmap of the environment it has just successfully traversed. And meta-human gifting lies in the fact that the complex and sophisticated activities of a nonhuman animal have facilitated the education of human animals through careful study of bees throughout our history. To paraphrase these insights at the level of the family of animal dance in general, according to Figuration, the grace of animal dance consists in its dramatization of practical activities, a process that highlights the importance for the species of activities that surpass the existential viability of any particular animal, and that, moreover, suggests an analogously greater importance of the sum total of nonhuman species relative to the human one. (The implications of the latter premise would lead us, for example, to repudiate human practices that perpetuate species extinction and climate change.)

Regarding "falling stars" or "shooting stars," their smooth and rapid progress through the night sky lends itself to the commonsensical notion of grace. Grace finds superabundant playfulness in the apparently nonchalant end of the existence of the so-called "star" (in fact, they are meteorites rather than actual stars). Figure/ ground reversal manifests in the fact that stars, which normally fade into the background to illuminate scenes of purposeful human activity, take on a more robust sense of agency and redirect the human mind to a cosmic world beyond earth. And meta-human gifting lies in the fact that minerals from former stars serve as the material basis for human eyes-which eyes gaze on the final moments of other stars' lives, light years away. ${ }^{63}$ To paraphrase these insights at the level of the family of astronomical dance in general, according to Figuration, the grace of astronomical dance consists in the apparent triviality, relative to human perception, of cosmically significant phenomena-phenomena that ironically point to the cosmos as a site of independent meaning that, in turn, makes the human observation of the cosmos possible in the first place.

And finally, the reader or listener experiences the commonsensical notion of grace in Neruda's poetry, particularly in the smooth transitions (1) among images and sounds, denotations and connotations, as well as (2) among physical and metaphysical, personal and social aspects of reality. Grace finds superabundant playfulness in Neruda's democratization, and seemingly chaotic intermixing, of all these aspects of language and reality. Figure/ground reversal manifests in the 
paradox that what is meaningful for humans becomes the background against which the antics of the nonhuman and the meaningless are staged for their own sake. And meta-human gifting lies in Neruda's redirecting of the divine aims of poetry toward the prehuman and nonhuman layers of the earth. To paraphrase these insights at the level of the family of discursive dance in general, according to the Figuration philosophy of dance, the grace of discursive dance emerges in the equalizing of various aspects of reality through language, where language slips its yoke of practicality in order to gesture toward the nonhuman forces that constitute the human and constantly reweave us.

\section{Conclusion}

To recap this presentation of the third Move of Figuration theory, the etymology of "grace," from the ancient Greek kharis, shows its dual meaning of beautiful power. An etymological analysis of grace as "beautiful force" in three of Schiller's major works reveals that, for him, grace is central to the play impulse, the naive way of thinking/being/writing, and the perfect transformation of matter into beauty. A conceptual analysis of grace in Dewey's Art as Experience leads me to crystallize grace as "organism/environment reversal" and to establish its intimate linkage with rhythm and, thereby, its foundational import for dance. Finally, an application of the Move of grace to a series of specific instances of actual and metaphorical dances reveals this Move's versatility and efficacy in explaining the stylistic powers of dance-in short, the aesthetically potent communication of which dance is capable.

\section{Notes}

1. See Joshua M. Hall, Figuration: A New Philosophy of Dance (Ph.D. diss., Vanderbilt University, 2012), http://etd.library.vanderbilt.edu/available/etd-07192012-180322/.

2. For an overview of phenomenology, see Edmund Husserl, The Essential Husserl, ed. Donn Welton (Indianapolis: Indiana University Press, 1999); and Martin Heidegger, Basic Writings, ed. David Farrell Kress (New York: Harper, 2008).

3. See, for example, J. L. Austin, How to Do Things with Words, 2nd ed., ed. J. O. Urmson and Marina Sbisà (Cambridge, MA: Harvard University Press, 1975).

4. Friedrich Schiller, On the Aesthetic Education of Man (New York: Dover, 2004); Friedrich Schiller, "On Naïve and Sentimental Poetry," in Essays: Friedrich Schiller, eds. Walter Hinderer and Daniel O. Dahlstrom (New York: Continuum, 1993), 179-260; and Friedrich Schiller, "Kallias or Concerning Beauty: Letters to Gottfried Körner," in Classic and Romantic German Aesthetics, ed. J. M. Bernstein (Cambridge: Cambridge University Press, 2003), 145-84.

5. John Dewey, Art as Experience (New York: Perigee, 2005).

6. See William F. Wertz, Jr., "A Reader's Guide to Schiller's Letters on the Aesthetical," Fidelio, vol. 14, nos. 1-2 (2005): 80-104.

7. See William F. Wertz, Jr., trans., “Introduction' to 'Friedrich Schiller: Kallias, or On the Beautiful,"” Fidelio, vol. 1, no. 4, (1992): 53-56.

8. Schiller, On the Aesthetic Education of Man, 23.

9. Ibid., 25, 27. 
10. Ibid., 27-28.

11. Ibid., 31.

12. See, for example, Andrew Hewitt, Fascist Modernism: Aesthetics, Politics, and the AvantGarde (Palo Alto, CA: Stanford University Press, 1993), 61.

13. Schiller, On the Aesthetic Education of Man, 47, 58.

14. Ibid., 48.

15. Ibid., 54, 54-55.

16. See Susan McClary, "Music, the Pythagoreans, and the Body," in Choreographing History, ed. Susan Leigh Foster (Indianapolis: Indiana University Press, 1995), 82-104.

17. Schiller, On the Aesthetic Education of Man, 56-57.

18. Ibid., 63.

19. See Joshua M. Hall, "Core Aspects of Dance: Condillac and Mead on 'Gesture," Dance Chronicle, vol. 36, no. 3 (2013): 352-71; Joshua M. Hall, "Slanted Truths: The Gay Science as Nietzsche's Ars Poetica," Evental Aesthetics (forthcoming); Joshua M. Hall, "Syncopated Communities: Dancing with Ellison," Southern Literary Journal, vol. 45, no. 2 (2013): 57-71; Joshua M. Hall, "Choreographing the Borderline: Dancing with Kristeva," Philosophy Today, vol. 56, no. 1 (2012): 49-58; and Joshua M. Hall, "Self-Mimetic Curved Silvering: Dancing with Irigaray," Journal of French and Francophone Philosophy, vol. 22, no. 1 (2014): 76-101.

20. Schiller, On the Aesthetic Education of Man, 74, 78, 78.

21. Ibid., 76 (all quotes in this paragraph).

22. Ibid., $79,80,80$.

23. Ibid., $81,82,82$.

24. Ibid., 84 .

25. Ibid., 87.

26. Ibid., 101.

27. Ibid., 106.

28. Ibid., 126.

29. Ibid., 133, 134.

30. Ibid., 136, 139, 140.

31. Schiller, "On Naïve and Sentimental Poetry," 190.

32. Ibid., 182, 183; 184; 185.

33. Schiller, "Kallias or Concerning Beauty,” 152, 153, 154, 154.

34. Ibid., 164.

35. Ibid., 173.

36. Ibid., 174.

37. See, for example, Stuart Hopps (choreographer), Sense and Sensibility, directed by Ang Lee (Los Angeles: Columbia Pictures, 1995), DVD; and Sue Lefton, Emma, directed by Douglas McGrath (Santa Monica: Miramax, 1996), DVD.

38. Dewey, Art as Experience, 1, 1,2.

39. Ibid., $3,5,5$.

40. Ibid., 12, 12, 12, 13.

41. Ibid., $15,18$.

42. Ibid., 153, 175, 185.

43. John Dewey and Arthur F. Bentley, Knowing and the Known, in The Later Works of John Dewey, vol. 16, ed. Jo Ann Boydston (Carbondale: Southern Illinois University Press, 2008), 119.

44. Dewey, Art as Experience, 61.

45. Ibid., 66 .

46. Ibid., 69.

47. Ibid., 75 . 
48. Ibid., 101.

49. Ibid., 154, 158 (only last quote).

50. Ibid., 231.

51. Ibid., 236-37.

52. Jean Newlove, Laban for Actors and Dancers (New York: Routledge, 1993), 11, 13.

53. Ibid., 22,70 .

54. Ibid., 70, 71, 73 .

55. Ibid., 75,114 .

56. See Avicenna, The Metaphysics of The Healing, trans. Michael E. Marmura (Provo, UT: Brigham Young University Press, 2005).

57. See, for example, Rudolf Laban, Choreutics (Alton, Hampshire, UK: Dance Books, 2011), $18,27$.

58. See André Levinson, André Levinson on Dance: Writings from Paris in the Twenties, eds. Joan Acocella and Lynn Garafola (Hanover, NH: Wesleyan University Press), 42.

59. Laban, Choreutics, 30.

60. Levinson, André Levinson on Dance, 73.

61. Laban, Choreutics, 39.

62. Levinson, André Levinson on Dance, 54.

63. Charles Scott, The Lives of Things (Bloomington: Indiana University Press, 2002), 99-112.

JOSHUA M. HALL is an assistant professor of philosophy at CUNY, Queensborough. His current research focuses various historical and geographical lenses on philosophy's boundaries, particularly at the intersection of aesthetics, psychology, and social justice. His publications include a coedited anthology on philosophical practices in prisons, Philosophy Imprisoned; thirty peer-reviewed journal articles (in Philosophy and Literature, Journal of Aesthetic Education, and Southern Literary Journal, among others); nine anthology chapters (for example, in Mind on the Move: Reflections at the Intersection of Dance and Cognitive Science); and thirty conference presentations, including three invited-speaking engagements, and presentations for the American Psychological Association, and all three divisions of the American Philosophical Association. His related work in the arts includes one chapbook collection and sixty-five individual poems, appearing in literary journals internationally, including multiple Pushcart Prize winners Ibbetson St. Magazine, Main Street Rag, and Shampoo, and twenty years of experience as a choreographer, instructor, and performer. 